\title{
Assessment of public perception on urban environmental problems by using $Q$ methodology
}

Neslihan Doygun a,* (i)

\begin{abstract}
This study aimed to determine perception of urban environmental problems in İzmir and İstanbul, two big cities of Turkey. Q methodology, which enables classifying human subjectivity through different perspectives bringing together the strong aspects of both qualitative and quantitative research methods, has been used as the research methodology. As a result of analysis of the participants' views on urban environmental problems, which were sorted according to a certain guideline, two factors, in other words, two points of views were determined. Discrepancy correlation values of the factors were low, therefore, results states that the discrepancy of the two factors shows the represented point of views are clearly distinct. Significant majority of the participants from both cities agreed on factor 1 that "air pollution" is the primary environmental problem due to urbanization regardless of education background and gender. The other group forming factor 2 agreed on "smell pollution" as the primary environmental problem due to urbanization. The issues forwarded by the participants in this study significantly overlapped with the previously determined environmental problems of the two cities. As a conclusion, it has been pointed out in this study that Q methodology is an important tool in determining social opinions and priorities; guiding or supporting research; enlighten managers and planners in improving the effectiveness of their works.
\end{abstract}

Keywords: Urban environment, Environmental problems, Q methodology

\section{Q metodoloji kullanılarak halkın kentsel çevre sorunlarına yönelik algısının belirlenmesi}

\begin{abstract}
Özet: Bu çalışmada, Türkiye'nin iki büyük kenti olan İstanbul ve İzmir örneğinde, kentsel çevre sorunlarına yönelik algının belirlenmesi amaçlanmıștır. Nitel ve nicel araștırma yöntemlerinin güçlü yönlerini bir araya getirerek insan öznelliğini farklı bakış açıları doğrultusunda gruplandırmaya olanak tanıyan Q metodoloji bu araştırmada yöntem olarak kullanılmıştır. Katılımcıların belirli bir yönerge doğrultusunda sıraladığı konuyla ilgili ifadelerin analiz edilmesi sonucunda, kentsel çevre sorunlarına yönelik iki faktörün yani iki bakış açısının olduğu belirlenmiştir. Faktörler arasındaki görüş farklılıklarını yansıtan korelasyon değerleri düşük çıkmış olup, bu durum her iki faktörü temsil eden bakış açılarının net bir şekilde birbirinden ayrıldığını işaret etmektedir. Araştırmaya her iki şehirden katılanların önemli bir çoğunluğu, eğitim veya cinsiyet farkı gözetmeksizin 1 nolu faktörde buluşmuşlar ve hava kirliliği kentleşmeye bağll öncelikli çevre sorunu olarak belirtilmiştir. Diğer grubun meydana getirdiği 2 nolu faktörde ise koku kirliliği öncelikli çevre sorunu olarak belirlenmiştir. Katılımcılar tarafindan belirtilen konular, bu kentler için varlığı daha önceden tespit edilen çevre sorunları ile önemli ölçüde örtüşsmüştür. Sonuç olarak bu çalışmada, Q metodolojisinin sosyal görüşlerin ve önceliklerin belirlenmesine yönelik araştırmaların desteklenmesinde ve geliştirilmesinde, yöneticilerin ve planlamacıların çalışmalarının etkinliğini artırmada önemli bir araç olduğu vurgulanmıştır.

Anahtar kelimeler: Kentsel çevre, Çevre sorunları, Q metodoloji
\end{abstract}

\section{Introduction}

Urbanization is a complex socio-economic process that transforms the built environment, converting formerly rural into urban settlements. In practice, urbanization refers both to the increase in the percentage of population residing in urban areas and to the associated growth in the number of urban dwellers, in the size of cities and in the total area occupied by urban settlements (United Nations, 2019). On the other hand, creating dramatic and rapid changes globally, rapid urbanization growth has led to the need to understand urbanization as a major contributor to not only socio-economic transformation but also resource consumption and environmental damage (Zhang, 2016). Land uses are changing because of urbanization that has significant impacts on environment (Limin et al., 2019), agricultural lands and forests are diminishing (Kara and Keçeli, 2017), wetlands losses are experienced (Rojas et al., 2019), coastal ecosystems are harmed (Zhai et al., 2020) and water flow systems are changing (White and Greer, 2006). In addition, urbanization causes environmental pollutions that have the potential of negative effects on human health such as air (Liu et al., 2017), water (Gao et al., 2016), noise (Doygun and Gurun, 2007), soil (Peng et al., 2013) and smell (Müezzinoğlu et al., 2000). At the same time, due to urbanization and related land use changes, heat island effect and climate changes in terms of warming emerge (Gao and Liu, 2011; Dihkan et al., 2015; Sun et al., 2016).

Globally, more people live in urban areas than in rural areas, with $55 \%$ of the world's population residing in urban areas in 2018. In 1950, 30\% of the world's population was urban, and by $2050,68 \%$ of the world's population is

\footnotetext{
$\bowtie$ a Izmir Democracy University, Higher Vocational School, Department of Landscape and Ornamental Plants, Izmir, Turkey

@ * Corresponding author (İletişim yazarı): neslihan.doygun@idu.edu.tr

$\checkmark \quad$ Received (Geliş tarihi): 24.09.2020, Accepted (Kabul tarihi): 18.11.2020
}

Citation (Atıf): Doygun, N., 2020. Assessment of public perception on urban environmental problems by using $\mathrm{Q}$ methodology. Turkish Journal of Forestry, 21(4): 481-488. DOI: $10.18182 /$ tjf.799763 
projected to be urban (United Nations, 2019). This trend being experienced on world demographics gives important clues that effects of urbanization on environment and humans will constantly increase. Ironically, although urbanization emerged as a result of efforts to improve the quality of life of the mankind, the possible negative effects on the environment during the process will eventually hit back human life. In fact, many researchers have hypothesized that individual well-being may be considerably affected by the physical, social, and economic environment in which the individuals are situated (Winters and $\mathrm{Li}, 2015)$. Since human welfare is directly related to environmental conditions, it can be interpreted that environmental qualities of the cities where people intensely inhabit will be more and more effective on a lot more people's welfare. Humans interact with the environment through their perceptions and this indicates that the way humans perceive the environment also play an important role on their welfare.

The main objective of this study is to determine perceptions of the residents on environmental problems related to urbanization in two big sample cities, İstanbul and İzmir, of Turkey where $93 \%$ of the population live in cities (TSI, 2020). In order to determine the perceptions of the people on environmental issues in two cities, Q methodology, which currently has a widespread fields of use, was benefited from. $Q$ is a methodology that determines the subjectivity of human perceptions bringing together the strong tools of qualitative and quantitative research methods to study similarities and differences of people's perceptions on a certain issue (Brown 1980 and 1996). Q methodology provides the researcher with an opportunity to investigate the variety of accounts participants construct around a research question and is particularly good at identifying the complex interplay between these constructs (Pike et al., 2015).

The objectives of this study are $i$ ) to put forward public perception on urban environmental problems in two big cities of Turkey, $i$ i) to realise a sample study on the use of $\mathrm{Q}$ methodology, and iii) to develop proposals which can help researchers, policy-makers and planners to design effective policies in terms of building more liveable cities and societies.

\section{Materials and methods}

\subsection{Study area}

Two developed cities in Turkey were selected as the study area to conduct this study, İstanbul and İzmir (Figure $1)$.

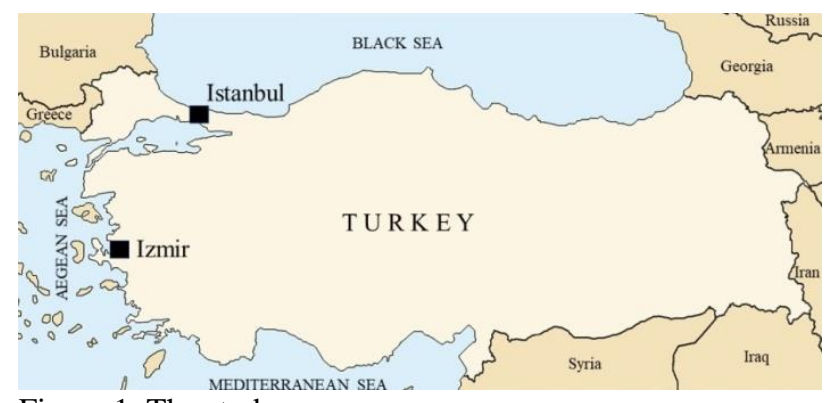

Figure 1. The study area
İstanbul, the most crowded and the biggest city in the country, is located in the north-western part of Turkey. Population of the city increased by $25 \%$ in the past 12 years. It was 12.5 million in 2007, but reached up to 15.5 million in 2019 (TSI, 2020). Depending on the population increase, number of motor vehicles also increased rapidly in the same period. The number of motor vehicles in Istanbul was 2.6 million in 2007, but increased to 4.2 million in 2019 (TSI, 2020). Also, great land use changes occurred in the province between the years 2003 and 2015. During that period, land use types in 57,391 ha area were converted to others (Kara and Keçeli, 2017). Urban built up land expanded by 27,277 ha, while forests and agricultural areas decreased by 9920 and 4603 ha, respectively. In parallel with this information, Dihkan et al. (2015) displayed that the extent of surface urban heat island is obvious with increasing magnitude in Istanbul for the period of 1984-2011.

Especially due to rapid population growth and urbanization, increasing amounts of pollutants caused some environmental problems in the city of Istanbul. Kuzu (2019) has specified that in spite of the fact that air pollution levels decreased gradually after the shift of coal with natural gas, sometimes, air pollution episodes are observed during winter time in Istanbul. In a recent report of NASA, $\mathrm{NO}_{\mathrm{x}}$ concentrations were decreased around the globe. But there was an increasing trend in some specific cities such as Istanbul. This shows that combustion sources affect the air pollution levels but sources were unclear. Çapraz et al (2016) found that short-term exposure to air pollution was associated with increased cardiovascular, respiratory and total non-accidental mortality in Istanbul during 2007-2012. On the other hand, according to noise map of Istanbul prepared by The Ministry of Environment and Urbanisation, $70 \%$ of the urban population are exposed to $<55 \mathrm{dBA}$ noise level, while $20 \%$ and $10 \%$ of the population are exposed to 55-64 dBA and >65 dBA, respectively (Köse, 2019).

Located in the western part of Turkey, the city of Izmir experienced $14 \%$ population increase, from 2.6 million in 2007 to 3 million in 2019. With 50\%, the number of motor vehicles showed great increase in the same period. It was 0.7 million in 2007 but reached to 1.4 million in 2019 (TSI, 2020). Land use types also changed drastically between the years 1984 and 2009 in the city (Nurlu et al., 2013). Artificial surfaces grew by 17904 ha during that period, while agricultural lands and scrub and herbaceous vegetation decreased by 3059 ha and 3318 ha, respectively. Forest areas increased by 1993 ha depending on the afforestation efforts. It was indicated that there was considerable difference of land surface temperatures between the urban and non-urban areas in Izmir (Yavasli, 2017). In the city, urban surface temperature increased in surroundings of industrial areas contrary to those in suburban areas. The heat island and hot spots were concentrated right in industrial areas and their adjacent nearby urban regions (Çorumluoğlu and Asri, 2015). Rapid population increase and urbanization also caused some environmental problems in Izmir. Sari and Bayram (2014) pointed out that air pollution has become a problem due to rapid urbanization in the city, and residential emissions decreases air quality in winter season. According to another study realised in six districts of Izmir for the period of 2007 and 2010, there was a statistically significant relation between the number of asthma cases and the level of urban air pollution (Ozcan and Cubukcu, 2015). In addition to the 
problems mentioned for Izmir, there was smell pollution in Izmir until recently. Regarding this pollution, which has largely been eliminated today, Müezzinoğlu et al. (2000) indicated that the city was suffering from rotten odours emitted by anoxic river mouths. Anaerobic conditions in the shallowest portion of İzmir Bay due to industrial and domestic wastewaters as well as eutrophication products in this very calm part of the Bay were responsible for this.

\subsection{An overview of $Q$ methodology}

Developed by Stephenson (1953) as an alternative measurement technique to existing scales and tests which provides assessment of human subjectivity (Davies and Hodge, 2007; Klooster et al., 2008), Q methodology uses viewpoints to construct typologies of different perspectives (Steelman and Maguire, 1999). Q methodology which contains factor analysis to extract patterns of similarities and differences between the responses of a small respondent sample (Davies and Hodge, 2007; Buchel and Frantzeskaki, 2015), has become a popular approach from the viewpoint of reflecting perceptions in a wide range such as education (Paro et al., 2009), politics (Lobinger and Brantner, 2016), administrative ethics (Graaf and Exel, 2008), health psychology (Collins et al., 2002), air pollution (Sala et al., 2015), climate change adaptation (Zivojinovic and Wolfslehner, 2015), ecosystem services valuation (Scholte vd., 2015), effects of land use change (Swaffield and Fairweather, 1996), rural research (Hermans et al., 2011), sustainable development (Doody et al., 2009), tourism studies (Jacobsen, 2007), and human geography (Eden et al., 2005).

A Q methodology study consists of mainly four stages: i) selection of $\mathrm{Q}$ statements, ii) determination of participants, iii) $\mathrm{Q}$ sorting, and $i v$ ) factor interpretation (Brown, 1993; Watts and Stenner, 2005; Webler et al., 2009). i) Q study begins with identifying a research question, and then a concourse of text that contains expressions of all the perspectives on that question is prepared. Whatever the research question is, the $\mathrm{Q}$ statements must always be broadly representative of the opinion domain at issue. Q statements can be elicited from academic literature, from both literary and popular texts (magazines, television programmes, etc.), from formal interviews, informal discussions and pilot studies. The issue which should be considered in the preparation of the statements is that each statement should have both positive and negative connotations. Because, as normal as it is for a statement to be accepted by some people, there may be people who can accept the opposite of it as true (Amin, 2000; Demir and Kul, 2011; Yıldırım, 2017). ii) Large numbers of participants are not required for a Q methodological study. Participants should be selected to represent the breadth of opinion in a target population, not the distribution of beliefs across the population. Q methodology aims to reveal some of the main viewpoints that are favoured by a particular group of participants. On the other hand, people who have well-formed opinions will find it easier to do the $\mathrm{Q}$ sort and are likely to produce a more robust sort. iii) At this stage, the participants are asked to rank order the statements on a chart which is designed considering the number of statements. In this process, the statements are administered in the form of a pack of randomly numbered cards (one statement to a card). The design model of the chart depends on the researcher. Forced or free distribution model can be chosen considering researcher's preference depending on whether he/she wants to crystallize the views of the participants or to give the participants opportunity to make the desired distribution. And then, the participants rank the statements (numbered cards) along a continuum from most agree at one end to most disagree at the other. iv) Q methodology employs a byperson correlation and factor analytic procedure. Once the factor is described in the language of the $Q$ statements it becomes a social perspective and the product of the Q study. The individuals' $\mathrm{Q}$ sorts are individual perspectives, the factor analysis solutions reflect deeper organizing principles, hence they are called social narratives (Stephenson, 1965).

\subsection{Design of the study procedure}

The statements which are used to put forward the public perception on urban environmental problems in the cities of Istanbul and Izmir were formulated based on literature review, expert and public opinions, respectively. To start with, 22 statements under two main headings were determined by reviewing related literature. The 22 statements were sent to $\mathrm{PhD}$ and $\mathrm{MSc}$ degree experts to examine them from the viewpoint of repetition, incoherency, deficiency, and redundancy. As a result of the control procedure, the number of statements were decreased to 15 . Finally, statements were voted by five different people considering meaningfulness, and the number of statements were decreased to 14 under two main groups (Table 1). After concretizing the statements, an opposite meaning statement was prepared for each, thus, a total of 28 statements were achieved.

As stated before, there is no need for a large number of participants for the Q methodology study, and 40-60 participants can effectively reveal the views on the subject (Stainton Rogers, 1995). On the other hand, it is possible to say that effective q methodology studies can be conducted with less number of participants (Watts and Stenner, 2005). Within this study, in the implementation of the methodology, a total of 40 participants, 20 from each city, were determined. Special attention was paid to the participants that they have been living in that city for at least 10 years. Thus, the prediction was that the participants who have sufficient opinion about study area could do the sorting process more consciously (Webler et al., 2009). 67\% of all participants were female, and $33 \%$ were male. $62 \%$ of the total has university degree, while $38 \%$ has high school degree. Distribution of gender and graduation degree according to the cities are given in Figure 2. 
Table 1. Statement groups used in the study

\begin{tabular}{ll}
\hline Pollution & \multicolumn{1}{c}{ Main statement groups } \\
\hline Urbanization causes soil pollution & Constructional development \\
Urbanization causes water pollution & Urbanization increases irregular constructional development \\
Urbanization causes air pollution & Urbanization causes decrease in agricultural areas \\
Urbanization causes noise pollution & Green areas become inadequate due to population growth in cities \\
Urbanization causes smell pollution & Increasing constructional development, traffic, industry etc. causes cities to get warmer \\
Urbanization causes visual pollution & Urban buildings block sunlight \\
& Urban buildings block air flows \\
& Urbanization increases global warming \\
& Urbanization causes decrease in natural habitats \\
\hline
\end{tabular}

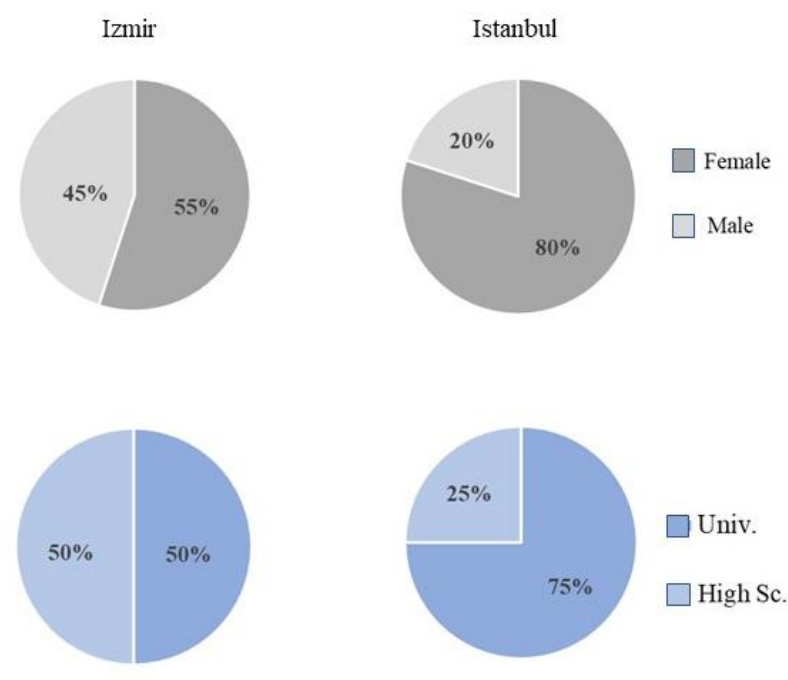

Figure 2. Distribution of gender and graduation among participants according to cities

The statements and the chart were prepared by using Microsoft Office 2016 program. First, 28 standard squares were prepared on PowerPoint, and the statements were written into squares randomly. Then, the statement page is converted to picture format, and every square were clipped onto a single statement card. The chart also was prepared using PowerPoint and converted to picture format. For the chart design, forced distribution model was chosen to crystallize the views of the participants. After preparation of statement cards and the chart, all of them were transferred onto a word page. On this page, it was possible to move the statement cards on the chart by using mouse and cursor (Figure 3). The files were sent to the participants via email and they were asked to place statements on the chart. After respondents sorted the statements, the resulting patterns were analysed through PQ Method 2.35 (Schmolck, 2014) which provides a simplified approach to data input and analysis.

Some criteria were taken into account in the creation of factors. Attention was paid to ensure that at least two people were involved in each factor (Brown, 1980; Watts and Stenner, 2005). To explain the perspectives with fewer factors (simplicity), that majority of the participants agreed on only one factor (clarity), lower correlations between factors (distinctness), and that intensity of participants doesn't change in trials on different factor numbers (stability) were also considered while revealing factors (Webler et al., 2009).

\section{Results}

When $\mathrm{Q}$ sorts done by the participants were analysed, two different factors, depending on the problems due to urbanization, in other words two different perspectives were identified. Correlation values representing the distinctions between factors were low in the study and this indicates that each perspective is clearly distinct from each other (Table 2).

In factor 1 , which includes $88.5 \%$ of the total participants, all participants from İstanbul and $75 \%$ of the participants from İzmir take place. This result shows that most of the participants from both cities agree on one common perspective. $10 \%$ of the participants from Izmir agreed on factor 2 which represents another perspective. On the other hand, $15 \%$ of the participants from İzmir did not put forward a clear point in terms of urbanization related problems, therefore, they didn't take part in any of the factors. When educational backgrounds of the participants were concerned, it can be stated that almost all of the university graduates and $75 \%$ of high school graduates agreed on factor 1. Similarly, almost all of the male and female participants agreed on factor 1 . When these evaluations on point of views of participants on urban environmental problems were analysed, results revealed that participants from two different big cities of Turkey can agree on the same perspective regardless of educational background and gender.

When the factors were investigated based on the statements agreed on, it is possible to make an evaluation by looking at the z-scores of the expressions, and it is understood that the expressions with a value of 1 and above are the most accepted by the participants. In this study, statements based on pollution were in the foreground in factor 1 , where the majority of the participants took part, while constructional development oriented statements were predominant in factor 2 (Table 3 ). In factor 1 , the most important urban environmental problem agreed on for İzmir and İstanbul is air pollution. Loss of natural habitats due to urbanization was stated as the second most important environmental problem. Other urban environmental problems in factor 1 are smell, water, visual and noise pollutions respectively.

Table 2. Correlations between factor scores

\begin{tabular}{lcc}
\hline & Factor 1 & Factor 2 \\
\hline Factor 1 & 1.0000 & 0.3775 \\
Factor 2 & 0.3775 & 1.0000 \\
\hline
\end{tabular}




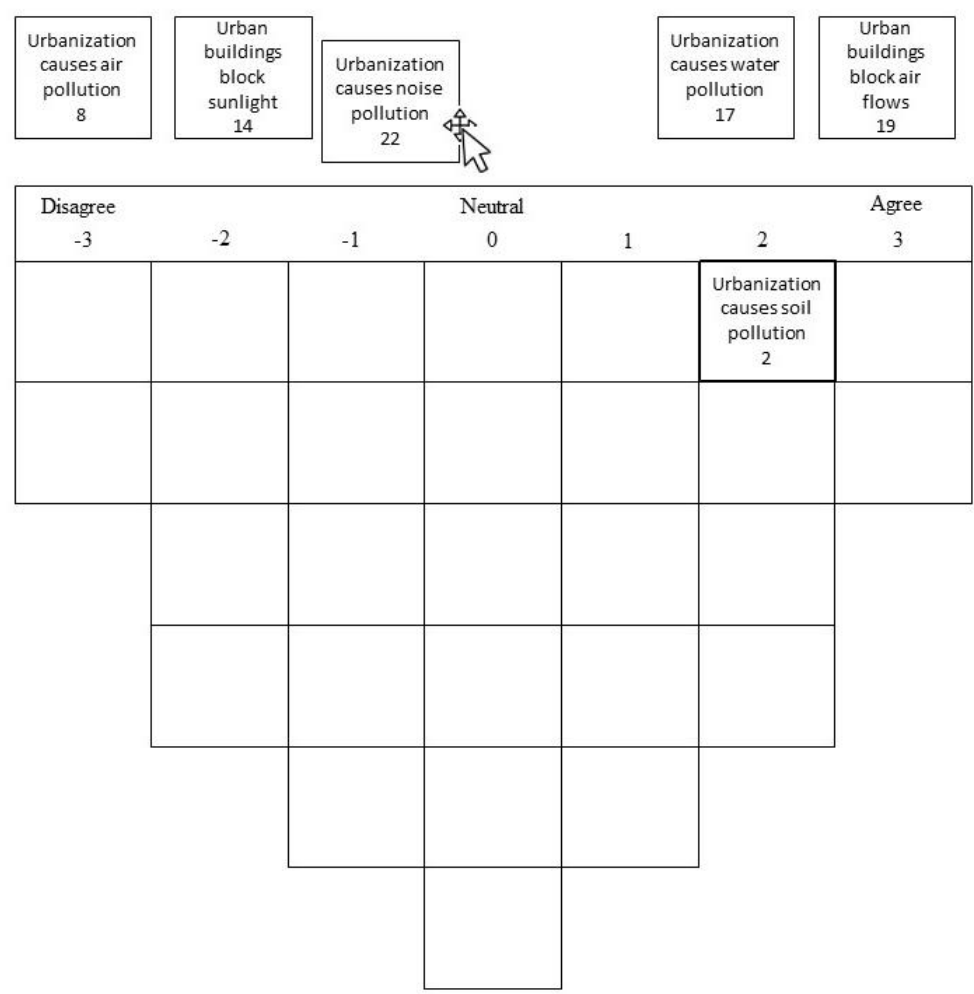

Figure 3. The chart used in this study, and some statements

Table 3. Factor based perspectives and main problems agreed on

\begin{tabular}{llll}
\hline & & Perspectives & Factor 2: Constructional development \\
\hline 1.481 & Factor 1: Pollution & Z-score & Smell pollution \\
1.398 & Air pollution & 1.669 & Regular urbanization \\
1.265 & Loss of natural habitats & 1.556 & Loss of natural habitats \\
1.158 & Smell pollution & 1.556 & Global warming \\
1.128 & Water pollution & 1.241 & Soil pollution \\
1.096 & Visual pollution & 1.128 & \\
\hline
\end{tabular}

When statements with z-scores 1 and above in factor 2 were investigated, it was observed that problems which were agreed on, formed a constructional development focused perception perspective. In this perspective, the primarily considered urban environmental problem was smell pollution. It was followed by constructional development problems in the next three places with and eyecatching statement saying urbanization is taking place according to a plan. Having had the second most important place in factor 2 this statement was not included in the preliminary statement set but later added as the opposite of the statement "urbanization increases irregular constructional development". As observed, the importance of including the opposites of the determined statements in the study is revealed once more. Because at the preparation phase of the Q statements they are expected to represent the related point of views comprehensively.

As explained in the methodology section as well, participants marked Q statements on the chart as "I don't agree" (-3), "I am undecisive" (0) and "I agree" (3) (Figure 3). In table 4, approximate information regarding how 28 statements, offered to the participants, were placed on the chart can be seen. Also, point of views which were either agreed or disagreed can be understood from table 4 . When table 4 is examined, it is seen that there is an agreement on factor 1 and 2 in terms of the existence of smell pollution in cities. Participants placed the statement "there is no bad smell in cities" to the edges of the chart, in other words, they disagreed with the statement. On the other hand, they placed the statement "urbanization causes smell pollution" on positive ends saying that they agree. In another example the statement "urban areas are quiet enough" was disagreed by -2 in both factors while the statement "urbanization causes noise pollution" was agreed it was prioritized differently as 2 and 1 respectively in factors. In addition, participants did not agree with the statement "natural habitats are not harmed by urbanization" by -1 and -2 respectively. They agreed with the statement "urbanization causes natural habitats to diminish" by 3 and 2 respectively. There is also an agreement in terms of indecisiveness of the participants, ranking the statements "Urban areas receive enough sunlight" and "visual quality is high in cities" as 0 , meaning they were neutral. Participants' views contradict for some statements. For example, the statement "urban constructions block the sunlight" had different rankings in factor 1 and 2 as 0 and -3 respectively. Similarly, the statements "urban green areas are adequate" and "urban constructional development is progressing in a planned fashion" were among contradicting point of views within factors. 
Table 4. Factor Q sort values for each statement

\begin{tabular}{|c|c|c|c|}
\hline No & Q Statements & Factor 1 & Factor 2 \\
\hline 1 & No bad smell is sensed in cities & -2 & -3 \\
\hline 2 & Urban areas get proper amount of sunshine & 0 & 0 \\
\hline 3 & Green areas become insufficient in cities due to population growth & 1 & -1 \\
\hline 4 & Urban areas are properly quiet & -2 & -2 \\
\hline 5 & Urban constructions block sunshine & 0 & -3 \\
\hline 6 & Urbanization causes agricultural lands to be opened to constructions & 0 & -2 \\
\hline 7 & There is no relation between water pollution and urbanization & -2 & -1 \\
\hline 8 & The process of global warming is not related to urbanization & -2 & 0 \\
\hline 9 & The air is clean in cities & -3 & 0 \\
\hline 10 & Urbanization increases irregular constructional development & 1 & -1 \\
\hline 11 & Air flows are blocked by constructional development & 0 & -2 \\
\hline 12 & Cities grow without harming agricultural lands & -1 & -1 \\
\hline 13 & Urbanization increases global warming & 1 & 2 \\
\hline 14 & Urban constructional development is progressing within a plan & -1 & 2 \\
\hline 15 & Urbanization causes air pollution & 3 & 1 \\
\hline 16 & Visual quality is high in cities & 0 & 0 \\
\hline 17 & Urbanization causes noise pollution & 2 & 1 \\
\hline 18 & The amount of urban green areas is sufficient & -3 & 1 \\
\hline 19 & Urbanization causes water pollution & 2 & 0 \\
\hline 20 & Natural habitats are nor harmed by urbanization & -1 & -2 \\
\hline 21 & Temperature levels in cities are same as other places & -1 & 1 \\
\hline 22 & Urbanization causes soil pollution & 1 & 2 \\
\hline 23 & Air flow is sufficient in cities & -1 & -1 \\
\hline 24 & Urbanization causes smell pollution & 2 & 3 \\
\hline 25 & Urbanization causes visual pollution & 2 & 1 \\
\hline 26 & Soil pollution and urbanization are non-related issues & 0 & 0 \\
\hline 27 & Increasing constructional development, traffic, industry etc. causes cities to get warmer & 1 & 1 \\
\hline 28 & Urbanization causes natural habitats to diminish & 3 & 2 \\
\hline
\end{tabular}

\section{Discussion and conclusion}

This study was conducted to determine the perceptions of the participants from two different big cities on urbanization related environmental problems. The main objective was to reveal how people perceive environmental pollution and how they prioritize these problems and find out different point of views, when there is. In the study, carried out in İstanbul and İzmir, first the pollution types determined in prior studies in these cities were investigated. Then, making use of those pollution types and similar studies conducted on the issue, a series of statements to help participants state their point of views. When Q sorts formed individually by each participant using the pre-determined statements, were examined it was observed that two factors, in other words, two opinions emerged in terms of urbanization related environmental problems. On factor 1, where the opinion urbanization causes more pollution intensified, most participants agreed. This is important because it shows that participants from two different cities can agree on one issue regardless of their educational background and gender. In factor 2 formed by participants from İzmir, effects of urbanization due to constructional development was focused on more. An important feature of this factor is that among the agreed issues the statement "urban constructional development is progressing in a planned fashion" took the second place. This statement is noticeable because of being the only positive statement on urbanization among 11 statements with z-scores higher than 1 in both factors.

In both factors, those statements ranked on top of the list of statements considerably overlapped the preliminary statements made based on previous studies. For instance, air pollution, effective in both cities and that it has been reported effective on some fatalities and health problems, became the primary statement in factor 1 where most participants agreed on intensively. The statement "urbanization causes natural habitats to diminish" was agreed on and placed in both factors. In fact, it has been reported for both İstanbul and İzmir that land uses have changed in vast areas and caused forests, scrub and herbaceous vegetation areas to shrink. Also, the statement "urbanization causes smell pollution" ranked high in both factors. The fact that this statement is ranked in the first place in factor 2 is considered to be due to the smell pollution once among the primary environmental problems emerging from the bay in İzmir. In factor one where participants from İstanbul took place, the statement "urbanization causes noise pollution" had a higher ranking. In fact, previous studies on the issue shows that $10 \%$ of the people, 1.5 million, in İstanbul are exposed to over $65 \mathrm{dBA}$ noise. The opinions revealed as results of $\mathrm{Q}$ sorting not only confirm the existing problems in cities but also and more importantly, gives clues about other problems people suffer from.

It is obvious that urbanization itself is a primary reason of stress in human lives. Studies show that psychiatric problems are observed more in urban areas than rural areas and these problems, depending on the environmental stress factors, occur more in number and also more complex in areas with intense urbanization. (Peen et al., 2007; Dekker et al., 2008). Environmental pollution has an important role on people's bad feelings. Air pollution is effective on developing anxiety and depression on humans (Pun et al., 2017). Bad environmental smell causes people to get stressed (Horton et al., 2009). When investigated, studies report that in developing countries, urbanization increases general health expenses (Çetin and Bakırtaş, 2019).

Introduced by William Stephenson, psychiatrics and physician, for the first time in 1935, the methodology was discussed in detail in 1953 (Stephenson 1935; 1953), and now it is being used more and more today to determine 
similar and contradicting opinions on any given subject in various disciplines. Q methodology provides researchers with diverse perspectives through enabling crystallization of opinions from limited number of participants who can forward opinions. The main requirement for the $Q$ methodology to be able to conduct is to predetermine the statements that enable participants to reflect their opinions from a broad perspective. Balance and representation of the statements are important factors that play key roles in identifying similar and contradicting opinions. If only positive statements are gathered from the literature, experts or pilot studies, it is necessary to create an opposite of each statement in order to establish the balance and that different opinions are expressed as well. This approach has another capacity in that different opinions can be gathered in terms of different factors in the analysis of $\mathrm{Q}$ sorting. These advantages provided by the unison of positive and negative statements have important effects on Q methodology to gain more disciplines to be used in.

Moving onwards from the results of this study and evaluations made, it is possible to develop a series of recommendations to researchers, planners and managers. From scientific research aspect, a more detailed research on the environmental issues that came front in this study can be considered. For instance, another study using Q methodology on air pollution, which was the primary problem forwarded by the participants, can be conducted on its causes, social effects and eradication of these effects investigating participant opinions. There is no doubt that the data to be gathered this way will be guiding or supporting the studies to detect pollution on site. Also, in contrast to this approach, on other environmental pollutions with no previous research but forwarded by the participants of this study projects can be developed. For instance, pollutions with no sufficient previous studies such as smell pollution for İstanbul and noise pollution for İzmir are among the potential study subjects. The data provided with this study accommodates important clues for planners and managers to be able to work more effectively and establish more liveable environments. For example, results of studies with Q methodology can be used to identify which priorities are to be considered in eradicating environmental problems. Projects to study pollutions, which were not investigated previously, but forwarded by the participants as disturbing in this study can be supported. In addition, studies with Q methodology can be generalized and can be used to gather different opinions and complaints in different parts of cities. This will also be an important guidance for the managers to identify their priorities. Efforts on eradicating disturbing environmental problems for individuals and the society will contribute to protecting public health and pulling down health expenses.

As a conclusion, it has been pointed out in this study that studies conducted with Q methodology is an important tool in determining social opinions and priorities; guiding or supporting research; enlighten managers and planners in improving the effectiveness of their works. The necessity of using Q methodology effectively not only limited to urban environmental problems but also on urban and rural landscape planning, nature preservation and coastal area preservation, is among other recommendations of this study.

\section{References}

Amin, Z., 2000. Q methodology - A journey into the subjectivity of human mind. Singapore Medical Journal, 41(8): 410-414.

Brown, S.R., 1980. Political subjectivity: Applications of Q methodology in political science. Yale University Press, New Haven, CT.

Brown, S.R., 1993. A primer on Q methodology. Operant Subjectivity, 16(3/4): 91-138.

Brown, S.R., 1996. Q methodology and qualitative research. Qualitative Health Research, 6(4): 561-567.

Buchel, S., Frantzeskaki, N., 2015. Citizens' voice: A case study about perceived ecosystem services by urban park users in Rotterdam, the Netherlands. Ecosystem Services, 12: 169-177.

Capraz, Ö., Efe, B., Deniz, A., 2016. Study on the association between air pollution and mortality in Istanbul, 2007-2012. Atmospheric Pollution Research, 7:147-154.

Çetin, M.A., Bakırtaş, I.., 2019. Does urbanization induce the health expenditures? A dynamic macro-panel analysis for developing countries. Dumlupinar University Journal of Social Sciences, 61: 208-222.

Collins, P., Maguire, M., O'dell, L., 2002. Smokers' representations of their own smoking: A Q-methodological study. Journal of Health Psychology, 7(6): 641-652.

Çorumluoğlu, O., Asri, I., 2015. The effect of urban heat island on Izmir's city ecosystem and climate. Environmental Science and Pollution Research, 22(5): 3202-3211.

Davies, B.B., Hodge, I.D., 2007. Exploring environmental perspectives in lowland agriculture: A Q methodology study in East Anglia, UK. Ecological Economics, 61(2-3): 323-333.

Dekker, J., Peen, J., Koelen, J., Smit, F., Schoevers, R., 2008. Psychiatric disorders and urbanization in Germany. BMC Public Health, 8(1): 17.

Demir, F., Kul, M., 2011. Q Method, A Modern Research Method. Adalet Yayınevi, Ankara.

Dihkan, M., Karslı, F., Güneroğlu, A., Güneroğlu, B., 2015. Evaluation of surface urban heat island (SUHI) effect on coastal zone: The case of Istanbul Megacity. Ocean \& Coastal Management, 118: 309-316.

Doody, D.G., Kearney, P., Barry, J., Moles, R., O’Regan, B., 2009. Evaluation of the Q-method as a method of public participation in the selection of sustainable development indicators. Ecological Indicators, 9(6): 1129-1137.

Doygun, H., Gurun, D.K., 2007. Analysing and mapping spatial and temporal dynamics of urban traffic noise pollution: a case study in Kahramanmaraş, Turkey. Environmental Monitoring and Assessment, 142(1-3): 65-72.

Eden, S., Donaldson, A., Walker, G., 2005. Structuring subjectivities? Using $\mathrm{Q}$ methodology in human geography. Area, 37(4): 413-422.

Gao, J., Liu, Y., 2011. Climate warming and land use change in Heilongjiang Province, Northeast China. Applied Geography, 31(2): 476-482.

Gao, Y., Liu, G., Hao, Y., Zhang, Y., 2016. Ecological network based urban pollution transfer effect analysis at a river basin scale. Energy Procedia, 104: 135-140.

Graaf, G., Exel, J., 2008. Using Q methodology in administrative ethics. Public Integrity, 11(1): 63-78.

Hermans, F., Kok, K., Beers, P.J., Veldkamp, T., 2011. Assessing sustainability perspectives in rural innovation projects using QMethodology. Sociologia Ruralis, 52(1): 70-90.

Horton, R.A., Wing, S., Marshall, S.W., Brownley, K.A., 2009. Malodor as a trigger of stress and negative mood in neighbors of industrial hog operations. The American Journal of Public Health, 3(99): 610-615.

Jacobsen, J.K.S., 2007. Use of landscape perception methods in tourism studies: A review of photo - based research approaches. Tourism Geography, 9(3): 234-253.

Kara, F., Keçeli, A., 2017. Impact of rapid urbanisation on land cover in Istanbul Province. Int International Journal of Environmental Research, 25(2): 293-302. 
Klooster, P.M., Visser, M., Jong, M.D.T., 2008. Comparing two image research instruments: The $\mathrm{Q}$ methodology method versus the Likert attitude questionnaire. Food Quality and Preference, 19(5): 511-518.

Köse, S., 2019. Determination of hotspots and development of solution methods for different noise sources within the scope of noise action plans in Istanbul. MSc Dissertation, Yildiz Technical University, Graduate School of Natural and Applied Sciences, Istanbul.

Kuzu, S.L., 2019. Source identification of combustion-related air pollution during an episode and afterwards in winter-time in Istanbul. Environmental Science and Pollution Research, 26(17): 16815-16824.

Limin, B., Chunliang, X,, Xinghua, F., Daqian, L., 2019. Influence of urbanization on regional habitat quality: A case study of Changchun City. Habitat International, 93: 1-13.

Liu, M., Huang, Y., Jin, Z., Ma, Z., Liu, X., Zhang, B., Liu, Y., Yu, Y., Wang, J., Bi, J., Kinney, P., 2017. The nexus between urbanization and PM2.5 related mortality in China. Environmental Pollution, 227: 15-23.

Lobinger, K., Brantner, C., 2016. Different ways of seeing political depictions: A qualitative-quantitative analysis using $Q$ methodology. Communications, 41(1): 47-69.

Müezzinoğlu, A., Sponza, D., Köken, I., Alparslan, N., Akyarlı, A., Öztüre, N., 2000. Hydrogen sulfide and odor control in Izmir Bay. Water, Air and Soil Pollution, 123(1-4): 245-257.

Nurlu, E., Erdem, U., Doygun, H., Oğuz, H., Atak, B.K., Doygun, N., Barut, I., Malkoç, E., 2013. The effects of land cover change on natural ecosystems: The case of Izmir, Turkey. Proceedings of ICOEST 2013: International Conference on Environmental Science and Technology18-21 June, Ürgüp, Turkey, pp. 371-378.

Ozcan, N.S., Cubukcu, K.M., 2015. Evaluation of air pollution effects on asthma disease: The case of Izmir. Procedia - Social and Behavioral Sciences, 202: 448-455

Paro, K.M., Siepak, K., Scott-Little, C., 2009. Assessing beliefs of preservice early childhood education teachers using Q-Sort methodology. Journal of Early Childhood Teacher Education, 30(1): 22-36.

Peen, J., Dekker, J., Schoevers, R.A., Have, M., Graaf, R., Beekman, A.T., 2007. Is the prevalence of psychiatric disorders associated with urbanization? Social Psychiatry and Psychiatric Epidemiology, 42(12): 984-989.

Peng, C., Ouyang, Z., Wang, M., Chen, W., Li, X., Ctrittenden, J.C., 2013. Assessing the combined risks of PAHs and metals in urban soils byurbanization indicators. Environmental Pollution, 178: 426-432

Pike, K., Wright, P., Wink, B., Fletcher, S., 2015. The assessment of cultural ecosystem services in the marine environment using Q methodology. Journal of Coastal Conservation, 19(5): 667675.

Pun, V.C., Manjourides, J., Suh, H., 2017. Association of ambient air pollution with depressive and anxiety symptoms in older adults: Results from the NSHAP study. Environmental Health Perspectives, 125(3): 342-348.

Rojas, C., Munizaga, J., Rojas, O., Martinez, C., Pino, J., 2019. Urban development versus wetland loss in a coastal Latin American city: Lessons for sustainable land use planning. Land Use Policy, 80: 47-56.

Sala, R., Oltra, C., Gonçalves, L., 2015. Attitudes towards urban air pollution: A Q methodology. Psyecology, 6(3): 359-385.

Sar1, D., Bayram, A., 2014. Quantification of emissions from domestic heating in residential areas of İzmir, Turkey and assessment of the impact on local/regional air-quality. Science of the Total Environment, 488-489: 429-436.
Schmolck, P. 2014. PQ Method Software, http://schmolck.org/qmethod/ Erişim: 02.05.2020.

Scholte, S., Teeffelen, A.J.A., Verburg, P.H., 2015. Integrating socio-cultural perspectives into ecosystem service valuation: A review of concepts and methods. Ecological Economics, 114: $67-78$

Stainton Rogers, R., 1995. Q methodology. J.A. Smith, R. Harre, L. Van Langenhove, (Eds.), Rethinking methods in psychology. Sage, London, s: 178-192.

Steelman, T.A., Maguire, L.A., 1999. Understanding participant perspectives: Q-Methodology in national forest management. Journal of Policy Analysis and Management, 18(3): 361-388.

Stephenson, W., 1935. Technique of factor analysis. Nature, 136:297

Stephenson, W., 1953. The Study of Behaviour: Q-Technique and Its Methodology. University of Chicago Press, Chicago.

Stephenson, W., 1965. Definition of opinion, attitude and belief. Psychological Record, 15(2): 281-288.

Sun, Y., Zhang, X., Ren, G., Zwiers, F.W., Hu, T., 2016. Contribution of urbanization to warming in China. Nature Climate Change, 6(7): 706-709.

Swaffield, S.R., Fairweather, J.R., 1996. Investigation of attitudes towards the effects of land use change using image editing and Q sort method. Landscape and Urban Planning, 35(4): 213 230.

TSI, 2020. Dynamic Statistical Query and Databases, Turkish Statistical Institute. http://www.turkstat.gov.tr/, Erişim: 22.04.2020.

United Nations, 2019. World Urbanization Prospects 2018: Highlights

https://population.un.org/wup/Publications/Files/WUP2018 Highlights.pdf, Accessed: 09.05.2020.

Watts, S., Stenner, P., 2005. Doing Q methodology: Theory, method and interpretation. Qualitative Research in Psychology, 2(1): 67-91.

Webler, T., Danielson, S., Tuler, S., 2009. Using Q Method to Reveal Social Perspectives in Environmental Research. Greenfield MA: Social and Environmental Research Institute. https://www.researchgate.net/publication/273697977_Using_Q Method_to_Reveal_Social_Perspectives_in_Environmental_ Research, Accessed: 01.05.2020.

White, M.D., Greer, K.A., 2006. The effects of watershed urbanization on the stream hydrology and riparian vegetation of Los Penasquitos Creek, California. Landscape and Urban Planning, 74(2): 125-138.

Winters, J.V., Li, Y., 2015. Urbanization, Natural Amenities, and Subjective Well-Being: Evidence from U.S. Counties. http://ftp.iza.org/dp8966.pdf, Accessed: 09.05.2020.

Yavaşl1, D.D., 2017. Spatio-temporal trends of urban heat island and surface temperature in Izmir, Turkey. American Journal of Remote Sensing, 5(3): 24-29.

Yıldırım, I., 2017. Eğitimin oyunlaştırılmasına ilişkin öğrenci algıları: Bir Q metodu analizi. Eğitim ve Bilim, 42(191): 235246.

Zhai, T., Wang, J., Fang, Y., Quin, Y., Huang, L., Chen, Y., 2020. Assessing ecological risks caused by human activities in rapid urbanization coastal areas: Towards an integrated approach to determining key areas of terrestrial-oceanic ecosystems preservation and restoration. Science of the Total Environment, 708: $1-14$

Zhang, X., 2016. Sustainable urbanization: A bi-dimensional matrix model. Journal of Cleaner Production, 134: 425-433.

Zivojinovic, I., Wolfslehner, B., 2015. Perceptions of urban forestry stakeholders about climate changeadaptation - A Qmethod application in Serbia. Urban Forestry and Urban Greening, 14(4): 1079-1087. 